\title{
MORPHOMETRY OF MEGAKARYOCYTES IN THE LIVER OF NEW ZEALAND WHITE RABBITS DURING INTRAUTERINE AND POSTNATAL DEVELOPMENT
}

\author{
MORFOMETRIA DE MEGACARIÓCITOS NO FÍGADO DE COELHOS \\ DA RAÇA NOVA ZELÂNDIA BRANCO DURANTE O DESENVOLVIMENTO \\ INTRA-UTERINO E PÓS-NATAL
}

\author{
Maria Rita Pacheco ${ }^{1}$ Nilson Ferreira ${ }^{2}$ Válder Rodrigues Melo ${ }^{3}$ \\ Silvana Martinez Baraldi-Artoni ${ }^{4}$ Antonio Marcos Orsi ${ }^{5}$ \\ Márcia Rita Fernandes Machado ${ }^{6}$ Fabrício Singaretti de Oliveira $^{7}$
}

\section{SUMMARY}

The hepatic megakaryocytic cells of New Zealand White rabbit in the intrauterine phase and in the immediate postnatal period were studied. Statistical analysis of the data concerning the cytoplasm and nucleus of those cells, i.e., area, perimeter, maximum diameter, minimum diameter, volume and shape factor, presented significant differences $(p<0.01)$ for $F$ values concerning the life phases studied on $15^{\text {th }}, 22^{\text {nd }}$ and $29^{\text {th }}$ day of intrauterine life and $10^{\text {th }}$ day of postnatal life, and for $F$ values for animal within each phase. The Tukey's test showed that most of the parameters studied in the cytoplasm and nucleus of these megakaryocytic cells presented the lowest values on the $15^{\text {th }}$ day of intrauterine life and the highest on the $22^{\text {nd }}$ day of the same phase.

Key words: liver, megakaryocytes, morphometry, rabbits.

\section{RESUMO}

As células megacariocíticas hepáticas de coelhos da raça Nova Zelândia Branco foram estudadas na fase intrauterina e no período pós-natal imediato. A análise estatística dos dados referentes ao citoplasma e núcleo dessas células, isto é, área, perímetro, diâmetro máximo, diâmetro mínimo, volume e fator de forma apresentaram diferenças significativas $(p<0,01)$ para os valores de F relativos às fases estudadas no $15^{\circ}, 22^{\circ}$ e $29^{\circ}$ dia de vida intra-uterina e $10^{\circ}$ dia de vida pós-natal, e para os valores de F para animal dentro de cada fase. O teste de Tukey mostrou que a maioria dos parâmetros estudados no citoplasma e núcleo dessas células apresentou os menores valores no $15^{\circ}$ dia de vida intra-uterina e os maiores no $22^{\circ}$ dia da mesma fase.

Palavras-chave: fígado, megacariócitos, morfometria, coelhos.

\section{INTRODUCTION}

In mammals, an early event after traumatic injury is the transitory contraction of the damaged blood vessels, but this has little effect on hemostasis (BERNE \& LEVY, 1990). However, 1 to 2 seconds after the occurrence of an endothelial lesion numerous platelets, essential for hemostasis, adhered to the damaged surface forming a dense aggregate. This is the beginning of the hemostatic plug, which is completed with the formation of a blood clot. Platelets contribute substances that accelerate clotting which are essential for clot retraction after clot formation. Furthermore, platelets release substances with vasoconstrictive properties, especially 5-hydroxytryptamine (5-HT or serotonin). There are indicative that platelets may be deposited

\footnotetext{
${ }^{1,4,6}$ Departamento de Morfologia e Fisiologia Animal da Faculdade de Ciências Agrárias e Veterinárias (FCAV), Universidade Estadual Paulista (UNESP). Rodovia: Carlos Tonanni, Km 5, 14884-900, Jaboticabal, SP. E-mail: rpacheco@fcav.unesp.br.

${ }^{2}$ Departamento de Cirurgia, Faculdade de Medicina Veterinária e Zootecnia (FMVZ), Universidade de São Paulo (USP), São Paulo, SP.

${ }^{3}$ Departamento de Morfologia, Faculdade de Medicina, USP. Ribeirão Preto, SP.

${ }^{5}$ Departamento de Anatomia, UNESP. Botucatu, Rubião Júnior, SP.

${ }^{7}$ Departamento de Clínica e Cirurgia Veterinária, FCAV, UNESP. Jaboticabal, SP.
} 
on the capillary endothelium, thus contributing perhaps to the integrity of the latter. Platelet depression or thrombocytopenia causes a hemorrhagic disorder, which manifests as persistent bleeding after cuts or wounds and as the appearance of petechiae, ecchymoses and blood leakage from capillary beds (MOUNTCASTLE, 1978).

In view of the essential role of megakaryocytes in the genesis of platelets, the objective of this study was to investigate parameters concerning the cytoplasm and nucleus of these cells in the liver of New Zealand White rabbits during intrauterine and immediately postnatal life development.

The morphometry of megakaryocytes contributes to the understanding of the hemostasis, as platelets, result from the fragmentation of the cytoplasm of these cells upon maturity and are characterized by a large ctyoplasm with proplatelet processes and with an irregular and multilobulated nucleus. Platelets are indispensable in this process by performing primary and secondary platelets aggregation, blood coagulation, lysis and removal of the coagulum.

It is known that parameters such as area, perimeter, maximum and minimum diameter and volume quantify the size of the cytoplasm and of the nucleus, and the shape factor determines the shape of the cytoplasm and nucleus, characterizing them as to the maturity or not of the cells.

This study was performed due to the scarcity of literature on the morphometry of megakaryocytes and on acount of the intense utilization of rabbits as laboratory animals.

\section{MATERIALS AND METHODS}

Twelve female New Zealand White rabbits were mated to males of the same breed. The pregnancies were verified by abdominal palpation and the animals were kept in individual metabolic cages fitted with fixed feeders and automatic water spounts, with food (production ration) and water ad libitum throughout the experimental period.

Hepatic megakaryocytopoiesis was studied during the intrauterine phase and during the postnatal period. Six rabbits were sacrificed on the $15^{\text {th }}, 22^{\text {nd }}$ and $29^{\text {th }}$ day of pregnancy, two per period, and the livers of $15^{\text {th }}$ day embryos and $22^{\text {nd }}$ and $29^{\text {th }}$ day fetuses were collected. Six other rabbits were allowed to complete pregnancy and, after parturition, the same study was conducted on 10, 21 and 32-day-old newborn animals. The liver of embryos, fetuses and newborns were fixed in Bouin's solution for 24 hours and routinely processed for paraffin embedding. Semiserial $7 \mu \mathrm{m}$ sections were obtained with a microtome, stained with Masson's trichrome (BEHMER et al., 1976) and observed under light microscope for morphometry.

The megakaryocytic cell parameters (area - $\mu \mathrm{m}^{2}$, perimeter - $\mu \mathrm{m}$, maximum diameter - $\mu \mathrm{m}$, minimum diameter $-\mu \mathrm{m}$, and volume $-\mu \mathrm{m}^{3}$ ) and the shape factor for the cytoplasma and nucleus of these cells were determined using the image analysis system of Kontron Elektronik (Video Plan, USA) coupled to a Zeiss binocular microscope. The shape factor, whose formula is mathematically expressed as $4 . \pi$.area/(perimeter) ${ }^{2}$, was programmed in the Video Plan memory, as also were the other parameters. The value of this factor ranges from zero to $1 \mu \mathrm{m}$ and when it is equal to one this means that the shape of the cytoplasm and/or nucleus is similar to a circle. This factor was indirectly calculated from the area of a circle expressed by the equation $\pi \cdot R^{2}$ and also from the perimeter of the circle expressed

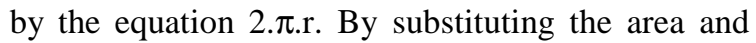
the perimeter, the shape factor $=4 \cdot \pi \cdot \pi \cdot \mathrm{R}^{2} /(2 \cdot \pi \cdot \mathrm{R})^{2} \rightarrow$ $4 . \pi \cdot \pi \cdot R^{2} / 4 \pi^{2} \cdot R^{2}=1$ was obtained. When this factor was less than one, this means that the shape of the cytoplasm and/or the nucleus is irregular. Values higher than one were rarely found for this shape factor.

The data concerning the variables parameters measured in the megakaryocytic cells were analyzed using a fully randomized design with four treatments, three during the intrauterine phase and one during postnatal life, in a hierarchical model. Five animals were used per treatment and 50 megakaryotytic cells were measured per animal. The mean values obtained at the various times were compared by the Tukey's test. The F test was used in analysis of variance to evaluate the effects of times of study $\left(15^{\text {th }}, 22^{\text {nd }}\right.$ and $29^{\text {th }}$ day of the intrauterine phase and $10^{\text {th }}$ day of the postnatal period) and of animals variations within each time according to the Statistical Analysis of Systems 'SAS' computational program.

\section{RESULTS}

The mean values and the statistical analysis obtained for the parameters measured were presented in the tables 1 and 2. Statistical analysis showed significant differences $(p<0.01)$ to the $F$ values for times and for animal within each period, concerning the parameters measured in the cytoplasm and nucleus on the $15^{\text {th }}, 22^{\text {nd }}$ and $29^{\text {th }}$ days of intrauterine life and on the $10^{\text {th }}$ day of 
Table 1 - F values, coefficient of variation and means obtained by analysis of variance for the parameters measured in the cytoplasm of cells of the megakaryocytic line.

\begin{tabular}{|c|c|c|c|c|c|c|}
\hline \multirow[b]{2}{*}{ Parameters } & \multicolumn{6}{|c|}{ Cytoplasm } \\
\hline & Area $\left(\mu \mathrm{m}^{2}\right)$ & $\begin{array}{l}\text { Perimeter } \\
(\mu \mathrm{m})\end{array}$ & $\begin{array}{c}\text { Maximum } \\
\text { Diameter }(\mu \mathrm{m})\end{array}$ & $\begin{array}{c}\text { Minimum } \\
\text { Diameter }(\mu \mathrm{m})\end{array}$ & Volume $\left(\mu \mathrm{m}^{3}\right)$ & Shape factor \\
\hline $\mathrm{F}$ for times & $82.48 * *$ & $87.40 * *$ & $68.70 * *$ & $85.50 * *$ & $65.02 * *$ & $10.06^{* *}$ \\
\hline F for animal within time & $3.91 * *$ & $4.57 * *$ & $4.25 * *$ & $3.46^{* *}$ & $3.92 * *$ & $3.70 * *$ \\
\hline Coefficient of variation & 37.44 & 20.53 & 19.34 & 19.32 & 60.14 & 13.61 \\
\hline $15^{\text {th }}$ day $(\text { IUP })^{1}$ & $183.32 \mathrm{C}$ & $52.19 \mathrm{C}$ & $18.24 \mathrm{C}$ & $13.62 \mathrm{C}$ & 1894.40C & $0.84 \mathrm{~A}$ \\
\hline Time means $22^{\text {nd }}$ day (IUP) ${ }^{1}$ & $313.42 \mathrm{~A}$ & $70.17 \mathrm{~A}$ & $23.27 \mathrm{~A}$ & $17.87 \mathrm{~A}$ & $4253.30 \mathrm{~A}$ & $0.80 \mathrm{~B}$ \\
\hline $29^{\text {th }}$ day (IUP) $)^{1}$ & $272.07 \mathrm{~B}$ & $65.22 \mathrm{~B}$ & $21.61 \mathrm{~B}$ & $16.74 \mathrm{~B}$ & $3404.60 \mathrm{~B}$ & $0.80 \mathrm{~B}$ \\
\hline $10^{\text {th }}$ day $(\mathrm{PNP})^{2}$ & $290.93 \mathrm{AB}$ & $64.61 \mathrm{~B}$ & $22.12 B$ & $16.83 \mathrm{~B}$ & $3780.80 \mathrm{~B}$ & $0.84 \mathrm{~A}$ \\
\hline
\end{tabular}

**Significant at the $1 \%$ level of probability $(\mathrm{p}<0.01)$

1 IUP: Intrauterine phase

2 PNP: Postnatal phase

A, B, C: In each column, the means followed by the same letter did not differ by the Tukey's test $(\mathrm{p}>0,05)$

postnatal life (Table 1 and 2). The Tukey's test also showed significant differences $(\mathrm{p}<0.05)$ between the mean values obtained for the cytoplasma and nucleus of these cells (Tables 1 and 2).

Significative differences in mean area, perimeter, maximum diameter, minimum diameter and cytoplasm volume were observed between the $15^{\text {th }}, 22^{\text {nd }}$ and $29^{\text {th }}$ days of intrauterine life. When these mean values were compared to those obtained on the $10^{\text {th }}$ day of postnatal life, only the area presented a significant difference between the $15^{\text {th }}$ day of intrauterine life and the $10^{\text {th }}$ day of postnatal life. The perimeter, maximum diameter, minimum diameter and volume differed significantly between the $15^{\text {th }}$ and $22^{\text {nd }}$ day of intrauterine life and the $10^{\text {th }}$ day of postnatal life. The shape factor for the cytoplasm of these cells differed significantly between the $15^{\text {th }}$ and the $22^{\text {nd }}$ and $29^{\text {th }}$ day of intrauterine life and significant differences were observed between the $22^{\text {nd }}$ and $29^{\text {th }}$ days of the intrauterine life and at $10^{\text {th }}$ day of postnatal life (Table 1).

Regarding the nucleus, significant differences were also observed between the mean values for area, perimeter, maximum diameter, minimum diameter and volume obtained on the $15^{\text {th }}$, $22^{\text {nd }}$ and $29^{\text {th }}$ days of intrauterine life. When these values were compared with those obtained on the $10^{\text {th }}$ day of postnatal life, significant differences in area, maximum diameter and volume were observed between the $15^{\text {th }}$ and $29^{\text {th }}$ days of intrauterine life and the $10^{\text {th }}$ day of postnatal life. A significant difference in cellular perimeter was also observed between the $15^{\text {th }}$ and $22^{\text {nd }}$ days of intrauterine life and in $10^{\text {th }}$ day of postnatal life. A significant difference in miniumum diameter was detected only between the $15^{\text {th }}$ day of intrauterine life and the $10^{\text {th }}$ day of postnatal life. The shape factor for the nucleus of these cells did not differ significantly between the $15^{\text {th }}, 22^{\text {nd }}$ and $29^{\text {th }}$ days of intrauterine life, but a significant difference was observed between the $15^{\text {th }}$ and $22^{\text {nd }}$ day of intrauterine life and the $10^{\text {th }}$ day of postnatal life (Table 2).

\section{DISCUSSION}

The observation that parameters measured in the cytoplasm and nucleus of cells of the megakaryocytic presented the liver of New Zealand white rabbits showed the lowest values on the $15^{\text {th }}$ day of intrauterine life and the highest on the $22^{\text {nd }}$ day of the same phase, and on the $10^{\text {th }}$ day of postnatal life for area, perimeter, maximum diameter, minimum diameter and volume allowing to leading the hypothesis that the morphofunctional mechanisms operating during hepatic megakaryocytopoiesis in this species are activated as early as on the $15^{\text {th }}$ day of intrauterine life, as shown by the visualization of a megakaryoblast (young cell of the megakaryocytic line) but must be more intense on the $22^{\text {nd }}$ day of intrauterine life.

On the basis of the data obtained here about the parameters measured in the cytoplasm and nucleus of these megakaryocytic cells, we thought it would be important to compare our results with those obtained by other investigators. In a cytometric light microscopy study of megakaryocytes of the vitelline sac, liver and bone marrow of mice, MATSUMURA \& SASAKI (1989) demonstrated that all the megakaryocites of the vitelline sac had a cytoplasm diameter of lesser than $10.00 \mu \mathrm{m}$ on the $10^{\text {th }}$ and $11^{\text {th }}$ days of pregnancy. Those investigators also detected "large" 
Table 2 - F values, coefficient of variation and means obtained by analysis of variance for the parameters measured in the nucleus of cells of the megakaryocytic line.

\begin{tabular}{|c|c|c|c|c|c|c|}
\hline \multirow[b]{2}{*}{ Parameters } & \multicolumn{6}{|c|}{ Nucleus } \\
\hline & Area $\left(\mu \mathrm{m}^{2}\right)$ & Perimeter $(\mu \mathrm{m})$ & $\begin{array}{l}\text { Maximum diameter } \\
\qquad(\mu \mathrm{m})\end{array}$ & $\begin{array}{l}\text { Minimum diameter } \\
\qquad(\mu \mathrm{m})\end{array}$ & Volume $\left(\mu \mathrm{m}^{3}\right)$ & Shape factor \\
\hline $\mathrm{F}$ for times & $51.63 * *$ & $37.16 * *$ & $49.98 * *$ & $47.11 * *$ & $41.14 * *$ & $7.34 * *$ \\
\hline $\mathrm{F}$ for animal within time & $3.33 * *$ & $4.76^{* *}$ & $3.51 * *$ & $2.71 * *$ & $3.40^{* *}$ & $4.71 * *$ \\
\hline Coefficient of variation & 44.21 & 26.32 & 20.85 & 23.49 & 69.44 & 27.50 \\
\hline $15^{\text {th }}$ day (IUP) $)^{1}$ & $71.48 \mathrm{C}$ & $39.45 \mathrm{C}$ & $11.79 \mathrm{C}$ & $8.72 \mathrm{C}$ & $529.33 \mathrm{C}$ & $0.61 \mathrm{~B}$ \\
\hline Time means $22^{\text {nd }}$ day (IUP) ${ }^{1}$ & $114.37 \mathrm{~A}$ & $50.68 \mathrm{~A}$ & $14.61^{\mathrm{A}}$ & $11.07 \mathrm{~A}$ & $1064.37 \mathrm{~A}$ & $0.58 \mathrm{~B}$ \\
\hline $29^{\text {th }}$ day (IUP) ${ }^{1}$ & 99.97B & 45.74B & $13.55 \mathrm{~B}$ & $10.31 \mathrm{~B}$ & $839.70 \mathrm{~B}$ & $0.62 \mathrm{AB}$ \\
\hline $10^{\text {th }}$ day $(\mathrm{PNP})^{2}$ & $113.75 \mathrm{~A}$ & $46.26 \mathrm{~B}$ & $14.31^{\mathrm{A}}$ & $10.74 \mathrm{AB}$ & $1021.75 \mathrm{~A}$ & $0.65 \mathrm{~A}$ \\
\hline
\end{tabular}

**Significant at the $1 \%$ level of probability $(\mathrm{p}<0.01)$

${ }^{1}$ IUP: Intrauterine phase

${ }^{2}$ PNP: Postnatal phase

A, B, C: In each column, means followed by the same letter did not differ by the Tukey's test ( $\mathrm{p}>0.05)$

megakaryocytes in the liver of 12-days fetuses, which increased in number thereafter, with variation in size between the $12^{\text {th }}$ and $15^{\text {th }}$ days of pregnancy. They also observed that, on the $15^{\text {th }}$ day of pregnancy and during the postnatal period, liver megakaryocytes presented a distribution, contour (perimeter), cell size (volume) and nucleus/cytoplasm ratio similar to those of bone marrow megakaryocytes of adult animals. The detection of large megakayocytes in the fetal mouse liver on the $12^{\text {th }}$ day of intrauterine life by those authors agreed with the results obtained in the present study. We assume that this similarity was due to the fact that, on the $12^{\text {th }}$ days of intrauterine life, the concepti of mice are fetuses, whereas in rabbits the embryo stage occurs on the $15^{\text {th }}$ day of intrauterine life and the fetal stage on the $22^{\text {nd }}$ day, when the highest mean values for the maximum diameter $(23,27 \mu \mathrm{m})$ and minimum diameter $(17,87 \mu \mathrm{m})$ of megakaryocytes were noticed. Thus, we believe that the differentiation of kidneys, liver, immunologic system, connective tissue and skin in the fetal stage made a greater potential contribution to elaboration of specific humoral substances inducing magakaryocytopoiesis, considering the relates of INOUE $\boldsymbol{e t}$ al. (1993), who observed by electron microscopy in megakaryocytes of rat bone marrow in vitro that the interleukin-6 significatively increased the megakaryocytes diameter. Indeed, according to MCDONALD et al. (1975), thrombopoietin is produced in the kidneys and, according to BANKS (1992), erythropoietin is synthesized in the kidneys and liver and interleukins are secreted by macrophages and helper $\mathrm{T}$ lymphocytes and also according to JUNQUEIRA \& CARNEIRO (1999), the interleukins are secreted by mast cells, fibroblasts, stroma of bone marrow, keratinocytes and monocytes. Those affirmations are in agreement with the literature papers as follows: BURSTEIN et al. (1992), studying the effects of interleukin-11 on megakaryocytes of murine and human bone marrow, in vitro, noticed that this cytokine promotes these cells maturation. INOUE $\boldsymbol{e} t$ al. (1993), researching in vitro megakaryocites of rat bone marrow using electronic microscopy, verified that the interleukin-3, interleukin-6 and erythropoietin stimulated, with variable potencial, the formation of cytoplasmic processes, which are intermediary structures between megakaryocytes and platelets in the sequence of maturation of these cellular lineage. It was also observed that the interleukin-6 supports the megakaryocytes ploidy. BURSTEIN (1994), investigating the effects of interleukin-6 on megakaryocytes and on the platelet function in dogs, noticed that these multifunctional cytokine is a potent promoter of megakaryocytic maturation, as shown by enhancing size, ploidt and platelet production. AN et al. (1994), studying mouse megakaryocytes, evidenced that the erythropoietin and interleukin-6 stimulated the development of cytoplasmic processes on these cells, considered proplatelet formation. TAJIKA $\boldsymbol{e t}$ al. (1996), researching trombocytopoiesis, in vivo and in vitro, by means of electron and immunofluorescent mycroscopy in megakaryocytes of mouses, which received interleukin-6 (10 mug/animal/day subcutaneously), verified bundle formation of microtubules in the cytoplasm in about half of these cells, in proportion to an increase in platelet counts. It was concluded that the microtubule-bundle formation is one maturational event in megakaryocyte development and that 
interleukin-6 could accelerate this event. ZUCKERFRANKLIN \& KAUSHANSKY (1996), investigating the effect of thrombopoietin on megakaryocytes culture isolated from the mouse bone marrow, perceived by ultrastructure that the thrombopoietin is able to drive the full maturation of the megakaryocytes as evidenced by generation of granules, demarcation membranes, and cytoplasmic fragmentation into platelets. TANGE \& MIYAZAKI (1996), studying the synergistic effects of erythropoietin, interleukin- 6 and thrombopoietin on megakaryocytes culture isolated from rat bone marrow, observed on both inverted phase contrast microscopy and scanning electron microscopy that a large number of proplatelet process clusters were dose-dependently formed with the addition of these substances. It was concluded that the erythropoietin and the interleukin-6 were demonstrated to act synergistically solely at low doses in the development of proplatelet processes formation leading to platelet release. On the other hand, in contrast to the data reported by MATSUMURA \& SASAKI (1989), we observed significantly higher mean values for the cytoplasmic and nuclear perimeters and volumes of liver megakaryocytes on the $10^{\text {th }}$ day of postnatal life compared to the $15^{\text {th }}$ day of intrauterine life. The fact that the cited authors did not detect this difference may have been due to the intense morphofunctional mechanisms operating in the hepatic magakaryocytopoiesis of mice (local microenvironment, thrombopoietin, erythropoietin and interleukins) during this period, keeping in mind that, according to KOLB (1984), the mean duration of pregnancy in mice is 23 days and that the concepti are already fetuses on the $15^{\text {th }}$ day of intrauterine life. In the present study, on the $15^{\text {th }}$ day of intrauterine life the organogenesis of rabbits was too premature to effectively contribute to the elaboration of the substances involved in megakaryocytopoiesis. However, we assume that, although the morphofunctional mechanisms inducing hepatic magakaryocytopoiesis in rabbits were not so efficient on the $15^{\text {th }}$ day of intrauterine life, the megakaryocytes showed a mean nuclear volume of $529.33 \mu \mathrm{m}^{3}$, quite similar and even greater than the $520.00 \mu \mathrm{m}^{3}$ mean value obtained for nuclei of megakaryocytes isolated from human bone marrow and studied by phase-contrast microscopy by HARKER \& FINCH (1969). We assume that, on the $22^{\text {nd }}$ day of intrauterine life, more effective morphofunctional mechanisms inducing megakaryocytopoiesis are active, since on this day we obtained the highest mean value, $4263.30 \mu \mathrm{m}^{3}$, for cytoplasm volume. We consider this result to differ little from the one of value $4700.00 \mu \mathrm{m}^{3}$ obtained for the cytoplasm volume of the megakaryocytes from human bone marrow by the last authors.

The mean values obtained here for cytoplasm and nuclear area $\left(\mu \mathrm{m}^{2}\right)$ of liver megakaryocytes were higher on the $22^{\text {nd }}$ day of intrauterine life but statistically similar to the mean values obtained on the $10^{\text {th }}$ day of postnatal life. We wish to point out that the mean cytoplasm area of megakaryocytic cells observed here on the $10^{\text {th }}$ day of postnatal life was $290.93 \mu \mathrm{m}^{2}$, a value quite similar to that reported by BRANEHÖG $\boldsymbol{e t} \boldsymbol{a l}$. (1975) $\left(296.00 \mu^{2}\right)$ for megakaryocytes from human sternum bone marrow, and clearly lower than the value of $313.42 \mu \mathrm{m}^{2}$ observed on the $22^{\text {nd }}$ day of intrauterine life in our study, however, lower than the area mean value $\left(398,70 \mu \mathrm{m}^{2}\right)$ evidenced in mouse splenic megakaryocytes by DAVIS $\boldsymbol{e t}$ al. (1992) after bone marrow ablation with strontium90. This high value observed in the mouse splenic megakaryoctyes led us to suggest that it could be a compensatory hypertrophy consequent to the bone marrow destruction. We believe that our results were due to the considerable hemocytopoietic potential of the liver on the $22^{\text {nd }}$ day of intrauterine life.

The mean values obtained here at the four time points for the shape factor of the cytoplasm of cells of the megakaryocytic line ranged from 0.80 to 0.84 , i.e., they were close to 1.00 , indicating that the shape of the cytoplasm was close to that of a circle (parameter $=1.00)$. In general the cytoplasmic contour was more circular in younger cells and more angular with some saliences and reentrances in mature cells. These different shapes may be explained by the dynamics and sequence of hepatic megakaryocytopoiesis in rabbits, as showed by COONEY \& SMITH (1965) when they reported that the time required for the full maturation sequence of megakaryoctyes was approximately three days in New Zealand White rabbits. According to the studies of HANDAGAMA $\boldsymbol{e t}$ al. (1986) on dogs and rats, these saliences may represent platelet precursor processes. We assume that the reentrances indicate possible segmentation of the cytoplasm and consequent release of platelet precursor cells which cross the walls of hepatic sinusoids in order to release platelets by fragmentation. This assumption is based on evidence reported by FEDORKO (1977) who, through a study of megakaryocytes from guinea pig bone marrow stimulated with agents promoting the platelet release reaction, which observed marked changes in cell shape in a scanning electron microscope. It is also based on data reported by HANDAGAMA et al. (1986) who, through a 
study of megakaryocyte morphology and of platelet formation in the bone marrow of dogs and rats, observed a complex and variable surface topography of megakaryocytes in a scanning electron microscopy.

The shape factor for the nucleus of these cells presented mean values ranging from 0.58 to 0.65 , i.e., not so close to 1.00 and therefore indicating that the shape of the nucleus was irregular (parameter < 1.00). These values reflected the oval, reniform and irregularly lobulated characteristic of the nucleus of these cells, clearly differing from the circular shape. According to JUNQUEIRA \& CARNEIRO (1999), the first two shapes are typical for nuclei of young cells and the third is typical for mature cells. WILLIAMS et al. (1983) and BANKS (1992) also described an irregularly lobulated nucleus for mature cells. We assume that, since these values did not differ significantly from one another during the intrauterine phase, equivalent numbers of young and mature cells existed during this phase, emphasizing once again the diligence and sequence of this event reported by COONEY \& SMITH (1965). The statistical similarity of the mean values observed on the $29^{\text {th }}$ day of intrauterine life and on the $10^{\text {th }}$ day of postnatal life possibly also indicates the presence of equal numbers of young and mature cells at these times. Few megakaryocytic cells were observed on the $10^{\text {th }}$ day of postnatal life, in agreement with HERTZBERG \& ORLIC (1981), who found few hepatic hemocytopoietic cells in New Zealand White rabbits at about 5 days of postnatal life. We infer that the evidence reported by these investigators also referred to megakaryocytic cells. Thus, we may state that although hepatic megakaryocytopoiesis is reduced at this time in rabbits, it is still biologically sequential, as shown by the numerical expression of the shape factor of the nuclei of these cells.

\section{ACKNOWLEDGEMENTS}

This work was supported by a grant from Fundação de Amparo à Pesquisa do Estado de São Paulo (FAPESP), Brazil. The authors thank gratefully Mr. Euclides Braga Malheiros for his help with the statistical analysis and the technical assistance of Mr. Orandi Mateus and Ms. Lúcia Helena Vasques.

\section{REFERENCES}

AN, E., OGATA, K., KURIYA, et $\boldsymbol{a l}$. Interleukin-6 and erythropoietin act as direct potentiators and induces of in vitro cytoplamic process formation on purified mouse megakaryocytes. Experimental Hematology, New York, v.22, n.2, p.149-156, 1994

BANKS, W.J. Histologia veterinária aplicada. 2.ed. São Paulo : Manole, 1992. p.208, 210, 375, 385.
BEHMER, O.A., TOLOSA, E.M.C., NETO, A.G.F. Manual de técnicas para histologia normal e patológica. São Paulo : Universidade de São Paulo, 1976. p.116-117.

BERNE, R.M., LEVY, M.N. Fisiologia. 2.ed. Rio de Janeiro : Guanabara Koogan, 1990. p.295.

BRANEHÖG, I., KUTTI, J., RIDELL, B., et al. The relation of thrombokinetics to bone marrow megakaryocytes in idiopathic thrombocytopenic purpura (ITP). Blood, Duluth, v.45, n.4, p.551-562, 1975.

BURSTEIN, S.A. Effects of interleukin-6 on megakaryocytes and on canine platelet function. Stem Cells, Oklahoma City, v.12, n.4, p.386-393, 1994.

BURSTEIN, S.A., MEI,R.L., HENTHORN, J., et al. Leukemia inhibitory factor and interleukin-11 promote maturation of murine and human megakaryocytes in vitro. Journal of Cellular Physiology, Oklahoma City, v.153, n.2, p.305-312, 1992.

COONEY, D.P., SMITH, B.A. Maturation time of rabbit megakaryocytes. British Journal of Haematology, Oxford, v.11, p. $484-487,1965$.

DAVIS, E., CORASH, L., STENBERG, P., et al. Histologic studies of splenic megakaryocytes after bone marrow ablation with strontium-90. Journal of Laboratory and Clinical Medicine, San Francisco, v.120, n.5, p.767-777, 1992.

FEDORKO, M.E. The functional capacity of guinea-pig megakaryocytes: I. uptake of ${ }^{3} \mathrm{H}$-serotonin by megakaryocytes and their physiologic and morphologic response to stimuli for the platelet release reaction. Laboratory Investigation, Baltimore, v.36, n.3, p. 310-320, 1977.

HANDAGAMA, P., JAIN, N.C., KOMO, C.S., et al. Scanning electron microscopic studies of megakaryocytes and platelet formation in the dog and rat. American Journal of Veterinary Research, Schaumburg, v.47, n.11, p.2454-2460, 1986.

HARKER, L.A., FINCH, C.A. Thrombokinetics in man. Journal of Clinical Investigation, New York, v.48, p.963974, 1969 .

HERTZBERG, C., ORLIC, D. An electron microscopic study of erythropoiesis in fetal and neonatal rabbits. Acta Anatomica, Basel, v.110, p.164-172, 1981.

INOUE, H., ISHII, H., TSUTSUMI, M., et al. Growth factor induced process formation of megakaryocytes derived from CFU-MK. British Journal of Haematology, Gunma, v.85,n.2, p.260-269, 1993

JUNQUEIRA, L.C., CARNEIRO, J. Histologia básica. 9.ed. Rio de Janeiro: Guanabara Koogan, 1999. p.217, 219, 220, 227.

KOLB, E. Fisiologia veterinária. 4.ed. Rio de Janeiro : Guanabara Koogan, 1984. p.403.

MATSUMURA, G., SASAKI, K. Megakaryocytes in the yolk sac, liver and bone marrow of the mouse: a cytometrical analysis by semithin light microscopic. Journal of Anatomy, London, v.167, p.181-187, 1989.

MCDONALD, T.P., CLIFT, R., LANGE, R.D., et al. Thrombopoietin production by human embryonic kidney cells in culture. Journal of Laboratory and Clinical Medicine, St. Louis, v.85, n.1, p.59-66, 1975. 
MOUNTCASTLE, V.B. Fisiologia médica. 13.ed. Rio de Janeiro : Guanabara Koogan, 1978. V.2, p.1039.

TANGE, T.,MIYASAKI, H. Sinergistic effects of erythropoietin and interleukin- 6 on the in vitro proplatelet process formation of rat megakaryocytes. Pathology International, Tokyo, v.46,n.12, p.968-976, 1996.

TAJIKA, K., IKEBUCHI, K., SUZUKI, E., et al. A novel aspect of the maturational step of megakaryocytes in thrombopoiesis: Bundle formation of microtubules in megakaryocytes. Experimental Hematology, Tokyo,v.24, n.2, p.291-298, 1996.

WILLIAMS, W.J., BEUTLER, E., ERSLEV, A.J., et al. Hematology. 3.ed. New York : McGraw-Hill, 1983. p.1186.

ZUCKER-FRANKLIN, D., KAUSHANSKY, K. Effect of thrombopoietin on the development of megakaryocytes and platelets: An ultrastructural analysis. Blood, New York, v.88, n.5, p.1632-1638, 1996. 